\title{
Theo Schoon and the case of the Pink Venus De Milo
}

\section{DAMIAN SKINNER}

\begin{abstract}
Theodorus Johannes Schoon (1915-1985) was a pioneering painter, printmaker, photographer, gourd and jade carver, and ceramicist. A Dutchman born and raised in Indonesia, he arrived in Aotearoa in 1939, where he used his sense of difference and being out-of-place to make art that challenged Pākehā attitudes and cultural values. This article considers how Indonesian art and Dutch colonialism prepared Schoon for his encounter with Māori art, resulting in an extraordinary and complicated relationship that left its mark on the visual arts in Aotearoa. ${ }^{1}$
\end{abstract}

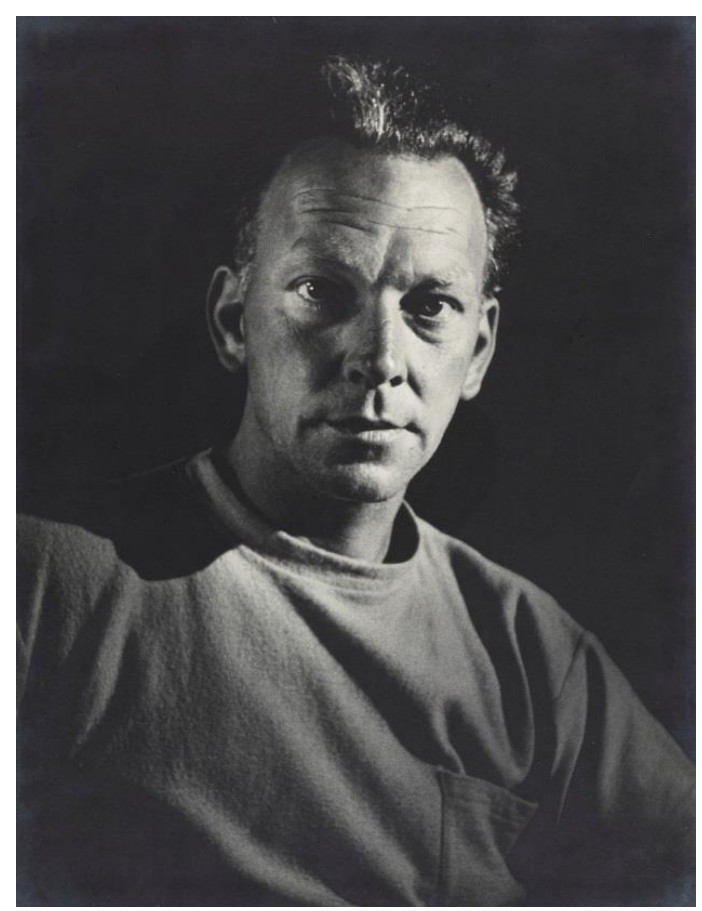

Figure 1: Theo Schoon, 13 December 1952. Photograph by Steve Rumsey. Te Papa Tongarewa, O.027677.

Later in his life, when Theo Schoon would summarise his personal history for new acquaintances, his early years in Java were always foremost in his mind. He might say, for example, that he was born of Dutch parents in Indonesia, and trained as an artist in Europe, before returning to Java where he worked as a portrait painter, making paintings of court dancers and the concubines of the local Rajahs. He would emphasise his abilities as a Javanese dancer, which he learned alongside the princes who were his schoolmates. He might talk about visiting Bali, where he also painted portraits of dancers, and met some of the celebrities who in the 1930s were visiting the 
island. He would offer a choice bit of gossip, such as the story of Paulette Goddard, the child bride of Charlie Chaplin, who scandalised the locals by kissing the lead boy dancer. But then Schoon's narrative would turn dark, become a tragedy. The Second World War broke out, and he found himself marooned in Aotearoa New Zealand - not just for the duration of the war, but, as it turned out, for decades, since the Netherlands eventually lost the Dutch East Indies and his white skin and Dutch name made him a target for those who resented colonialism and wanted to express it. ${ }^{2}$

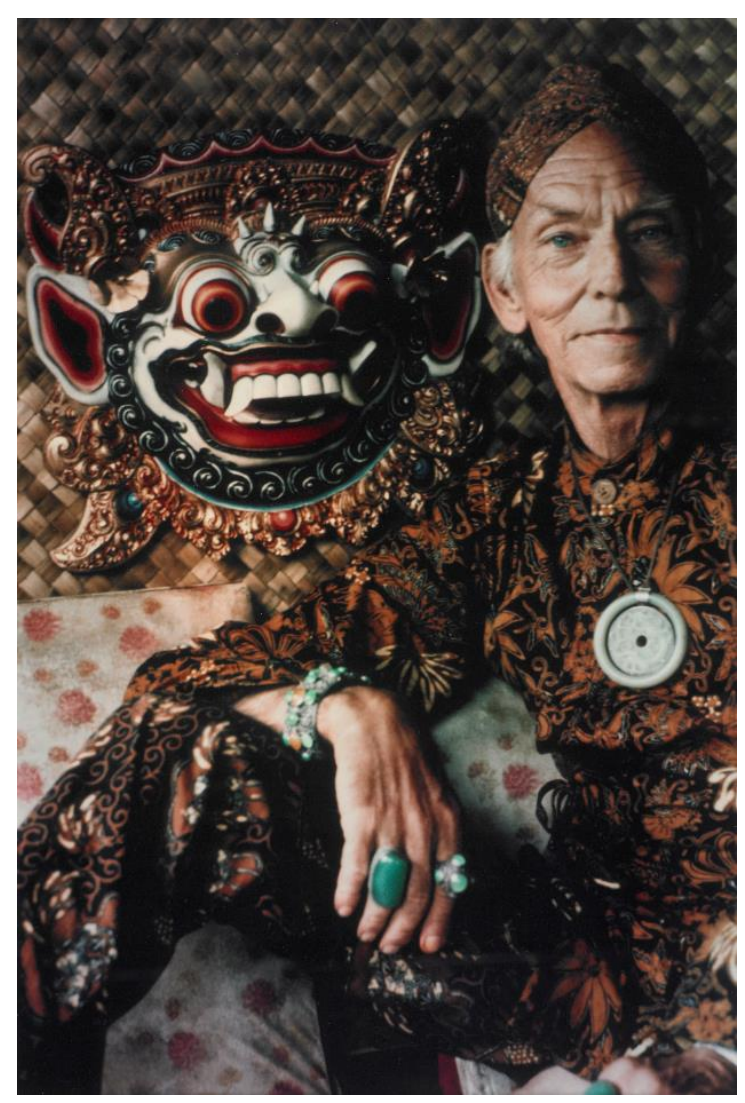

Figure 2: Schoon, in clothing of his own design made from batik cloth, poses with a mask of Rangda, processed July 1978. Photograph by Theo Schoon. Te Papa Tongarewa CA000841/001/0045.

Many years after he arrived in Aotearoa in 1939, Schoon still described his residence in this country as a kind of exile. It was only made bearable by his chance encounter with Māori art, which grew into an obsession and prevented him from leaving. In Māori art and culture, Schoon found objects and ideas and social patterns that evoked what he had left behind in Indonesia. And it was his childhood and early twenties in Java and Bali that explained his ability to see things that other Pākehā could not, and to be open to cultural difference in a way that was unusual in New Zealand society in the 1940s. "I can assure you," he wrote in 1966, "that I am only Dutch 
by half. The influence of the East has been far more powerful. It was my good parent's despair, that I never became a good Dutchman."3

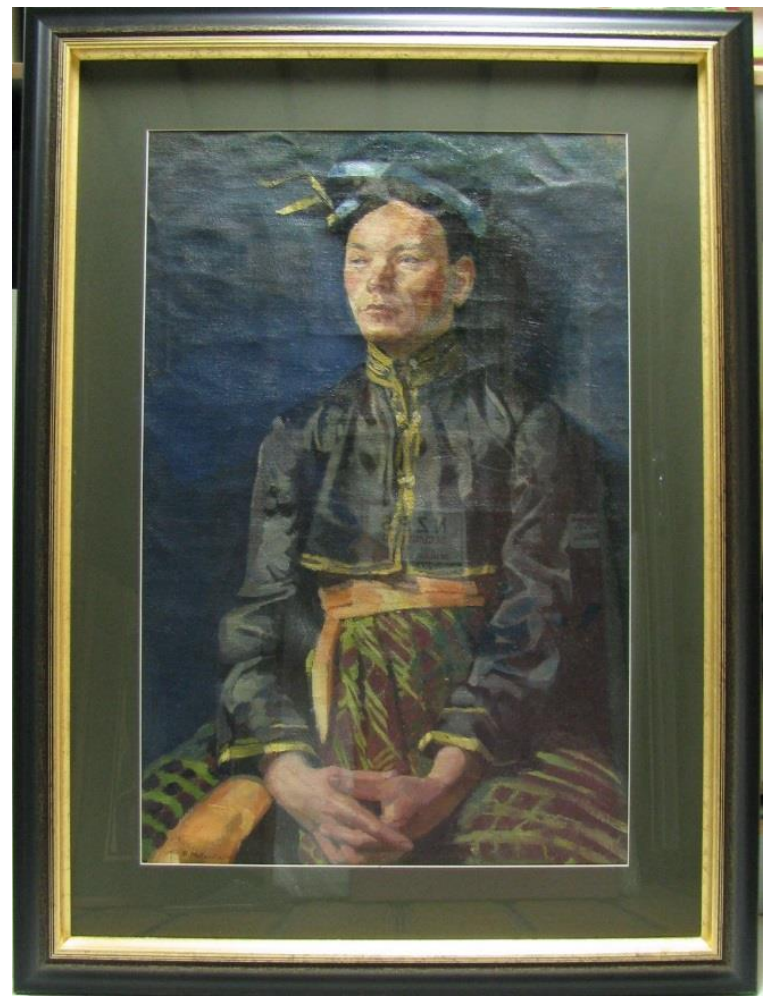

Fig.3 Portrait of Theo Schoon, circa 1946.

Painting by Barbara McKerchar. Eastern Southland Gallery, Gore, 08.003

Schoon claimed to feel out of step with European culture, whether it was the Dutch way of life that he encountered in the Netherlands during his teenage years or the transplanted British culture he found in Aotearoa. "I have nothing in common with the white New Zealand culture, which is Victorian and dead," he told one of his many correspondents. "But the Maori culture, decadent as it may be, still has colour, flavour, and that irrationality which never fails to baffle, astonish, and fascinate me." Prepared by a childhood in Indonesia, and the voracious appetite that art students in Europe had for what, in the 1930s, was called "primitive art," Schoon was ready for the encounter when it came. "Maori art has never been something that is 'on the other side of the fence," he told the historian Michael King in the late 1960s. "I only had the awareness, that I was ignorant unless I could absorb what it had to offer."

In this article, I consider how Indonesian art and Dutch colonialism prepared Schoon for his encounter with Māori art. It is a complicated story, which I will tell through two periods in Schoon's life: his childhood and early twenties in Java, and his interaction with Māori art and artists in the early 1960s in Aotearoa. Schoon was unusual and ahead of his time in promoting the idea of Māori art as extraordinary and powerful, and worthy of attention, yet he was also 
shaped by Dutch colonial attitudes that had much in common with the colonial outlook of Pākehā society. The result was a complicated and ambivalent relationship to Māori art. And this is the story I want to relate here.

\section{I}

Theodorus Johannes Schoon was born on 31 July 1915, in a small village outside the city of Kebumen, in the province of Central Java. Kebumen was part of the Dutch East Indies, which had grown from the colonies established by the United East India Company in the seventeenth century. Both his father and his mother were born in the Netherlands, as were Schoon's grandparents on both his mother's and father's sides, and there is no record of Indonesian ancestry in the artist's family tree. ${ }^{6}$ Schoon placed great importance on the fact of being born in Java, and insisted that the culture of his birthplace was fundamental to his attitudes, and his art. As he declared in the 1960s, "Since I was born in Indonesia, I have Eastern art in my blood." The family tree indicates that apart from this cultural transfusion, there were no facts of genealogy that might link him to this place and these people.

Schoon's father worked as the head of a reformatory school, but at some point in his professional life he was also associated with the thriving pottery industry in Java. It was in this connection that his son first encountered ceramics. In the early Hindu period there had been a lively art form in which strips and coils of terra cotta clay were shaped into figurines and constructions, with symbolic and magical significance. "Although only a few traces of the art are left," Schoon wrote in 1983, "in a limited range of domestic ware like piggy banks and children's toys in Java, I learned as a child that this art was still alive when a worker at my father's brick and tile factory was sent to mind me and he entertained me the way they entertain their own; by making clever and lively sculptures of people and animals from such strips and coils." 8

If that is the story of how Schoon first learned about ceramics, then here is the story of Schoon's first encounter with gourds. Imagine him on Passar, market day, the highlight of every child's week. Early in the morning, vendors wearing their brightest clothes would come from miles around, an amazing variety of merchandise piled on their heads and shoulders; like pied pipers, they would lead the local children along the main road to the market place, where their goods would be laid out for inspection and sale. One day, Schoon was surprised by an absurd little creature, peddling furiously, coming straight at him. It was a push toy featuring Petruk, one of the four punokawan or clowns from the Javanese puppet theatre, riding his monocycle. Made from two gourds on a wooden wheel with wooden legs and a bamboo stick, it was being pushed by a small boy who had come to market with his father. "The little gourd creature moved along crazily amongst bare and sandalled feet, baskets of spice, bales of cloth, meat covered with flies, billy-goats, bird cages, brightly coloured paper toys, until it suddenly came to a stop against a basket of dozing ducks," wrote Schoon in 1961. "There was instant pandemonium. The deafening quack of ducks and the angry chatter of the protesting vendor were doing a crazy cha-cha-cha, as people gathered to enjoy the spectacle and find out the cause of all this din."9

It was a childhood of sounds, and music. Every morning he would hear the subtle, complicated and shifting beat of women stamping rice, a hard and tedious job that was made more enjoyable

Journal of New Zealand Studies NS27 (2018), 50-73

https://doi.org/10.26686/jnzs.v0iNS27.5176 
by turning the rhythms into music. The heavy loads carried to market on bamboo yokes would squeak at every step, and became music by the size of steps, or the kind of gait, or subtle body movements which altered the tempo, and allowed the squeaks with their different pitch to be played like a kind of orchestra. Work, pain and weariness were transformed into art. ${ }^{10}$

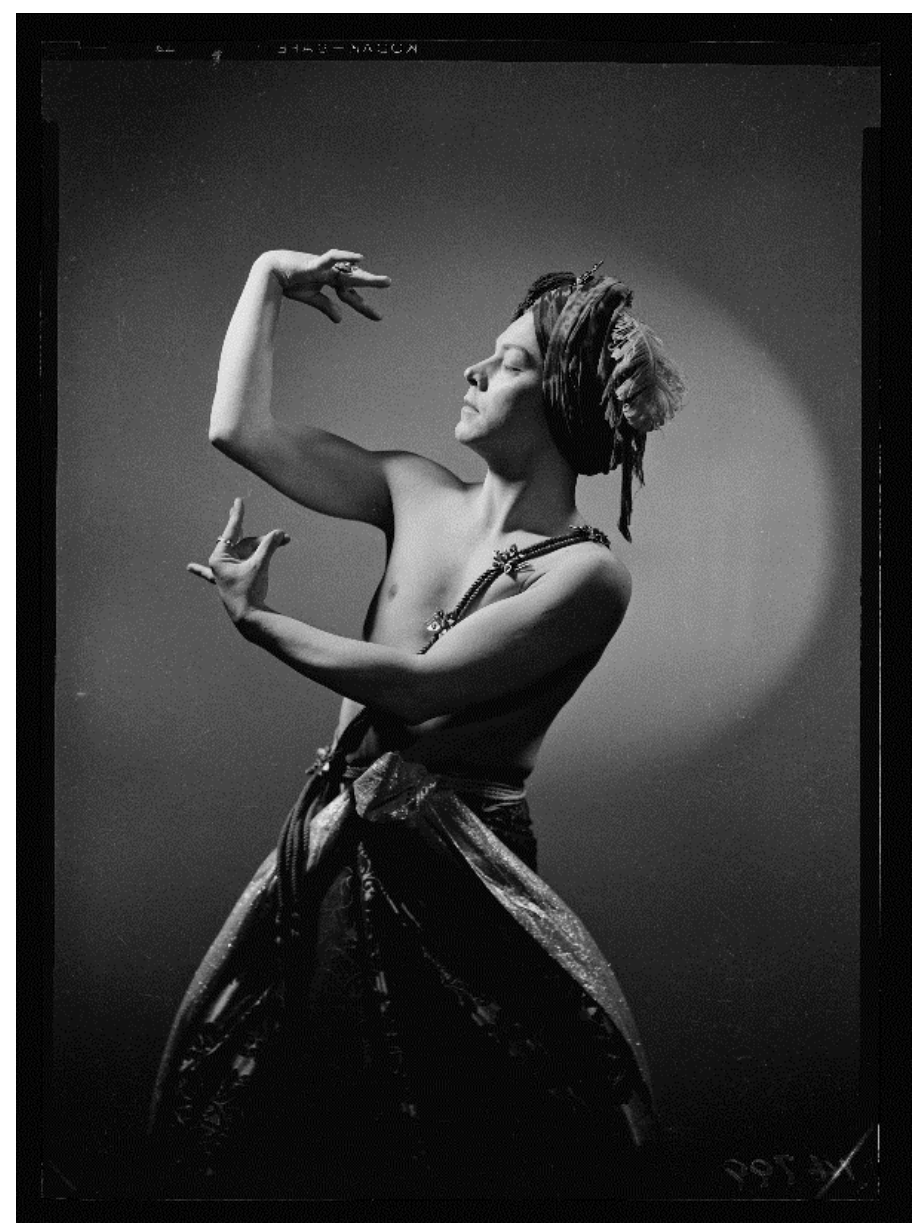

Figure 4. Theo Schoon as a Javanese dancer, published in the magazine Arts in New Zealand, 1944. 21 June 1943. Photograph by Spencer Digby Studios. Te Papa Tongarewa, B.076010

Schoon described himself as a "a classical Javanese dancer, up to professional standards," and said that he was introduced to Javanese dance at school, studying it alongside his aristocratic classmates. ${ }^{11}$ The best evidence of Schoon's childhood dance training was the way he moved: his physical grace and his elegance of gesture, and his ability to hold poses and perform hand gestures of different kinds. He was flexible and strong. One of his party tricks was to sit in a lotus position and then use his arms to push himself up, wobbling his legs in the air. He didn't use chairs, preferring to sit on the floor in a lotus position, just as he had learned to do at school. The 
pleasures of Javanese art and music, and the refined elegance of the Javanese aristocracy, were memories of a culture that stayed with him all his life. ${ }^{12}$

\section{II}

In 1927, when he was almost twelve years old, Schoon and his brother Pieter, who was three years younger, were sent back to Rotterdam in the Netherlands to receive a proper Dutch education. ${ }^{13}$ Nothing is known about Schoon's secondary education during this time. It is most likely that he went to one of the several Higher Civic Schools in Rotterdam, which had been specifically established to educate the children of the upper middle class. ${ }^{14}$ He studied languages, learning German and English. ${ }^{15}$ At some point, Schoon must have decided that he wanted to go to art school, and his parents agreed. When he was about sixteen years old, in 1931, he enrolled at the Rotterdam Academy of Fine Arts and Applied Sciences.

The curriculum of the Fine Arts department was based on the belief that skill and technique could be taught, but not originality. It was a traditional art education, and it set Schoon up by teaching him to observe closely and giving him access to superb technique. Days were spent in the Academy's studios, learning to draw correctly, the susurration of charcoal sticks and pencils whispering on paper, students looking up to study the plaster casts of ancient sculptures on the table before them, and then down to the image taking shape in front of them. Everything was subject to rules and techniques, to skills acquired by repetition. The injunction "don't draw what you think, just what you see" shaped everything that Schoon and his fellow students created. But once classes finished, these aspiring artists were let loose into the streets of Rotterdam, where they could go to galleries, gather together in coffeehouses for rowdy debates, and eagerly search the shelves of bookshops for the latest publications about modern art.

Schoon and his fellow students were keen on what was called "primitive art": objects from Africa and the Americas and the Pacific, made in a bewildering variety of materials, gathered together in the collections of anthropology museums. It was so excitingly different to the ancient Greek and Roman art that had been interpreted by Renaissance artists to create the western tradition that Schoon was being taught at the Academy. It was in a Rotterdam department store that Schoon first came across a book on African rock drawings by German ethnologist and archaeologist Leo Frobenius. Being one of the lucky students who could afford to buy books like this, thanks to the largesse of his parents, he took it home and pored over the text and illustrations; it was followed, a bit later, by another book on American Indian rock drawings, and then books about the cave drawings at Lascaux, France. ${ }^{16}$

Schoon did not yet have a way to realise the potential of his extracurricular reading. He was still mired in the academic conventions of his studies at the Academy. But what he was slowly collecting in the various books he purchased, read and discussed with his friends, were the tools he needed to go beyond his artistic education - to assert his own originality, and create the space that would let him consciously decide what he should value from his art school training, and what he should discard. The hunger for art from Africa or the Pacific gave birth, as Schoon saw it, to a new kind of visual literacy and a new global sophistication. It showed him that western academic art was actually quite parochial; claiming to be the ultimate standard in art, it was in

Journal of New Zealand Studies NS27 (2018), 50-73

https://doi.org/10.26686/jnzs.v0iNS27.5176 
fact just one of the world's art traditions. This must have been especially exciting for Schoon. Not only did he aspire to be a modern artist, but he treasured the Javanese art and culture of his childhood. What Schoon learned in Rotterdam in the early 1930s was that there could be a viable artistic connection between his love for Indonesian art and his future as a modern artist.

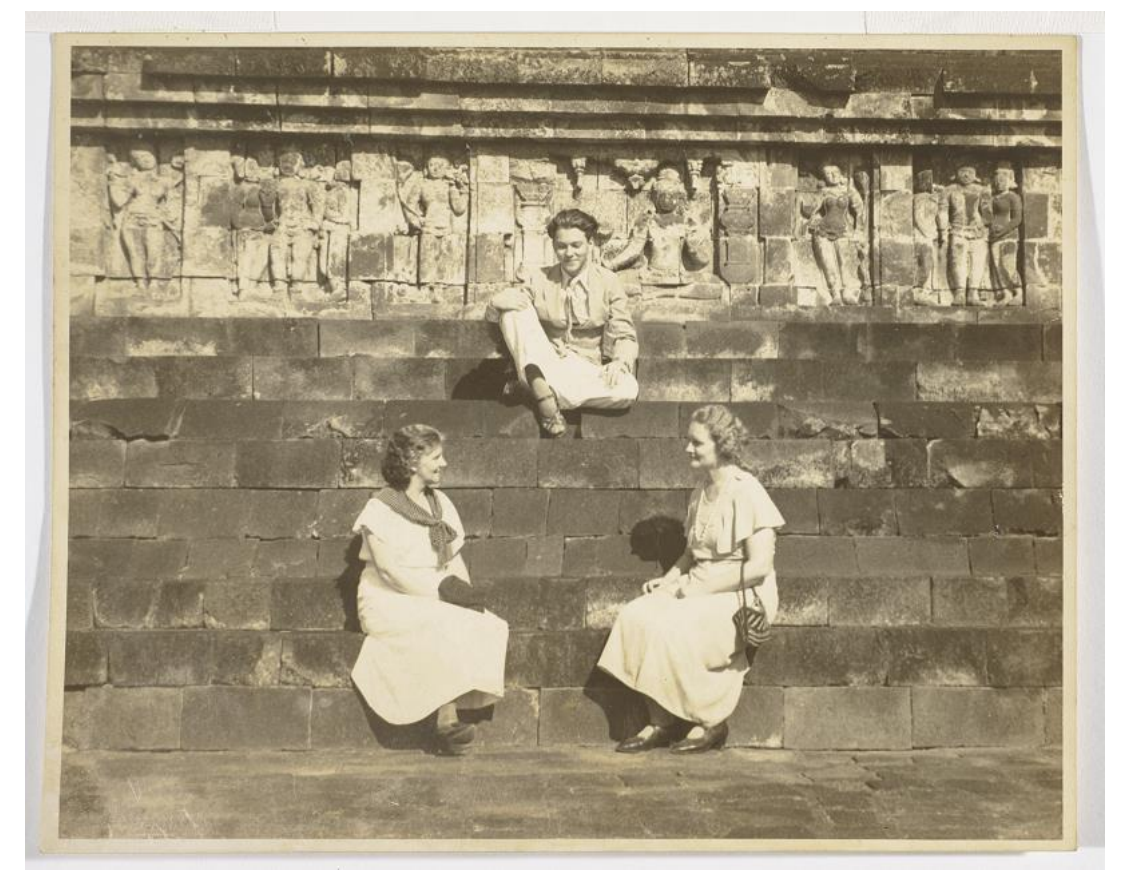

Figure 5: Theo Schoon (centre) and his mother, Barbara Schoon (left) at Borobudur in Java, circa 1936. Photograph by Theo Schoon. Auckland Art Gallery, 2014/14/2.

Schoon's decision to return to Indonesia in 1936 was driven by desire. "I was always pining for the richness of life in that 'backward' country Indonesia," wrote Schoon in the 1960s, "where life is a fascinating spectacle of costumes, the marketplace, the strangeness and variety of its produce and the artistic interest in every village." ${ }^{17}$ While he said that he sometimes found the "peasant mentality" of Indonesia exasperating, feudal societies had for him a "special beauty" that could not be found in the highly industrial west. "In fact," Schoon concluded, "I never liked Europe, and was far from happy there, during my years as an art student." 18

Imagine his return to Java, the boat growing ever closer to the heat and smells and sights of the tropics, until finally he arrived in the crowded and bustling port of Batavia, what is now Jakarta. Across town to the express train, surrounded by the Javanese people he remembered from his childhood, his luggage and transportation taken care of by the same system of servants and privilege that he remembered and no doubt missed. Once settled on the train, a jolt, the piercing scream of the whistle and clouds of steam marked the start of the journey, past the buildings and people of the city and then into the countryside, at first agricultural landscapes and then, upon waking the next morning, the mountains all around and in incredible shapes, like Chinese paintings, with banana groves and coconut palms. The train hurtled along the sides of steep gorges, through long tunnels, and over narrow bridges on spindly legs, the names of stations

Journal of New Zealand Studies NS27 (2018), 50-73

https://doi.org/10.26686/inzs.v0iNS27.5176 
along the way like poems returning him to his childhood. Then, finally, his destination, the station and modern city of Bandung that proudly sprawled across the highland plateau, fringed by mountains and volcanoes clad in verdant jungle. ${ }^{19}$

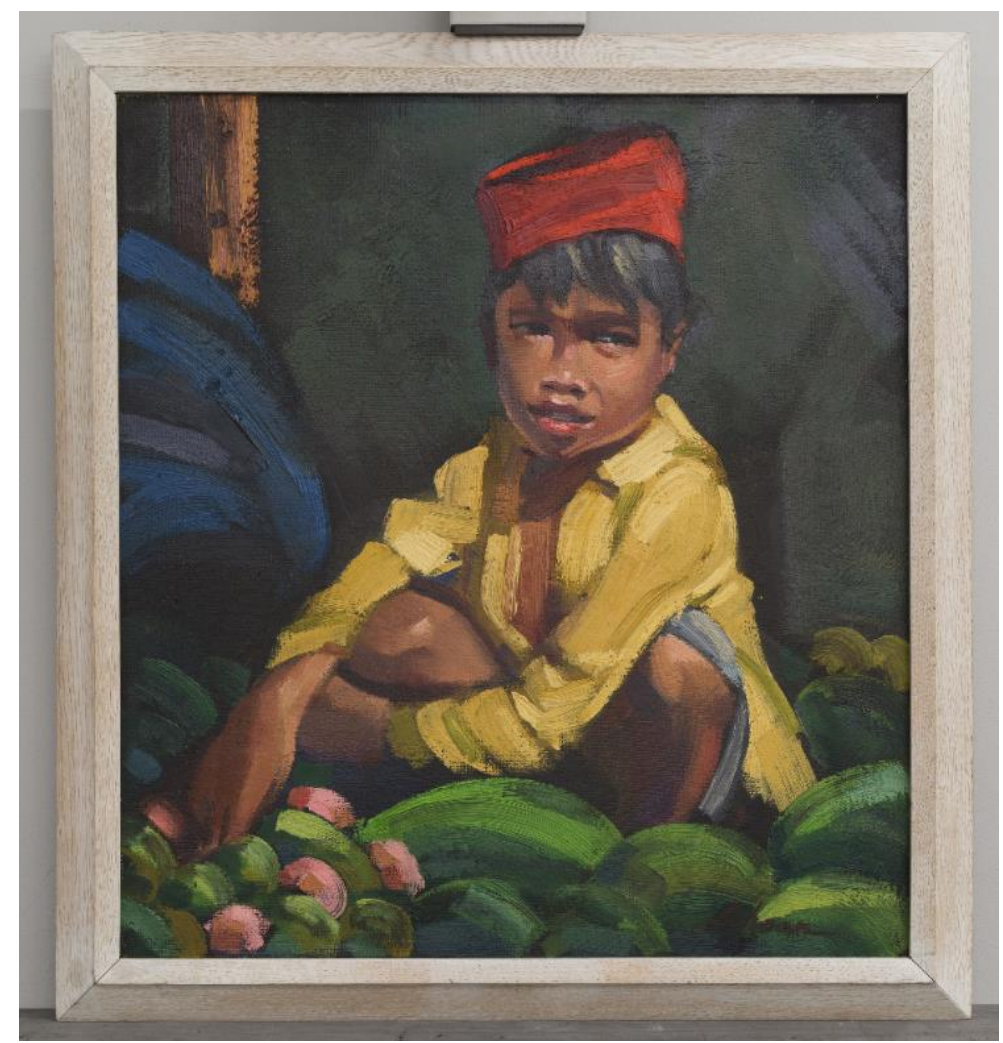

Figure 6: Fruit Market, Sudanese Boy, Java, circa 1939.

Painting by Theo Schoon. Dunedin Public Art Gallery, 6-1942.

Despite his enthusiasm for "primitive art," and whatever knowledge of modern European art he brought from the Netherlands, Schoon was an active member of the Beautiful Indies school. These paintings were sold alongside other souvenirs of Java and Bali-the batik cloth, wood carvings and brassware proudly displayed in Dutch homes - and they were marketed to people returning to the Netherlands who wanted the perfect memento of their time in the colonies. Typical subjects were landscapes, especially the dramatic scenery around Bandung, market scenes with smiling fruit sellers, still life paintings of tropical fruits and flowers, and cityscapes with flowering trees and exotically dressed natives. Above all, it was a conservative style of art, based on the kind of academic art training that Schoon received from the Rotterdam Academy. ${ }^{20}$ One of the most intriguing suggestions about this period is that Schoon met and worked with the artist Walter Spies in Bali. ${ }^{21}$ A German born in Russia, he was blond and handsome, with an aristocratic demeanour and a hint of a sardonic smile; he was a painter, a musician, a linguist; he was charismatic, with a sincere love for Balinese art and culture that won him many friends among visitors and locals; and he was gay. ${ }^{22}$ Spies lived in Ubud, a village in the uplands region with a stunning landscape of rainforests and terraced rice paddies, in a complex of houses that 
had been gradually expanded over the years to accommodate the increasing number of friends, celebrities and anthropologists who sought him out because of his reputation as a deeply knowledgeable and well-connected guide to the island, its people and culture.

The anthropologist Margaret Mead wrote that Spies had developed "a most perfect relationship between himself, the island, its people and its traditions." ${ }^{23}$ This must have been an intoxicating and overwhelming combination for Schoon, who was also searching for a way to make a life as an artist in the place he felt most at home- but where he, like Spies, was an outsider. Schoon would have had lots of reasons to make his way to Bali to meet, if not work with, the most famous European artist living in Indonesia in the 1930s.

It was an interesting time for Balinese art. In January 1936, Spies and his colleague, Dutch artist Rudolf Bonnet, had just set up an association of artists called Pita Maha (Great Spirit or Ancestor). It was a response to the growing numbers of tourists in Bali and their insatiable demand for local artworks as souvenirs of their visit to the island. From the early years of the twentieth century, patronage for Balinese art had begun to shift from the royal courts to the western tourists, and as a result, a new kind of Balinese art was emerging. Artists around Ubud, where Spies and Bonnet lived, painted activities and scenes of everyday life, rather than the epic stories and godly heroes of earlier Balinese painting. Initially in black ink and then coloured tempera on paper, Ubud artists married a sophisticated style with the subjects of daily life: farmers in a lively conversation as they walked next to their bullocks; a family scene in which a couple and their servant sit on the ground, one child contentedly nursing while the other wriggles out of the grip of his father and is calmed by the servant's funny faces and gestures; boys bathing in the river.

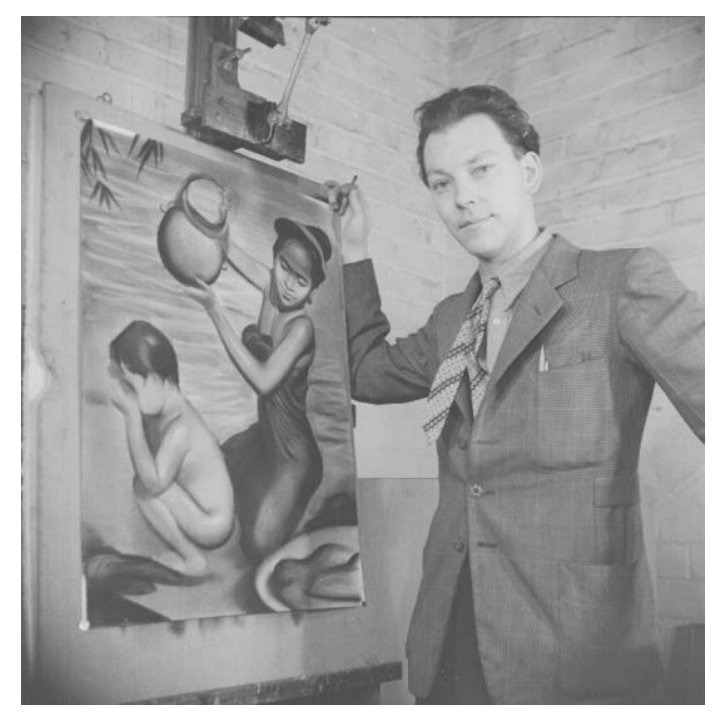

Fig.7 Theo Schoon with one of his Beautiful-Indies paintings in his basement studio in the Wellington YMCA, circa 1942. Te Papa Tongarewa, CA000841/001/0047

Journal of New Zealand Studies NS27 (2018), 50-73

https://doi.org/10.26686/jnzs.v0iNS27.5176 
Mead described Bonnet as "a mild, responsible, only a little twinkling Dutch artist who supplies system and bookkeeping to Walter's attempts to protect and encourage the Balinese artists to resist the tourists and do good work." "24 This is a little unfair, as Bonnet, even more than Spies, played a key role in supporting the new developments in Balinese art. While he might not have been as charismatic as Spies, Bonnet was Dutch and gay, and his art was more conservative and academic. He was a member of the Beautiful Indies school, painting a romantic vision of Balinese society untouched by modern life. His specialty was picturesque scenes of villagers working in the fields, or preparing for a dance, made up of conventional types rather than individuals. Schoon's own paintings at this time had much more in common with Bonnet's work, and very little to do with the dreamlike scenes of a metaphysical world of mountains, valleys and rice paddies that filled Spies's canvases. ${ }^{25}$

The intellectuals who gathered about Spies were attracted by the idea of Bali as a living museum, a Hindu enclave in a sea of Muslims that showed what Java must have been like before the triumph of Islam. This vision shaped Dutch colonial policy: while the Dutch may not have been very accurate about what Bali was actually like, they were very sure what it should be like. The goal was to protect the precious heritage of ancient Javanese culture found in Bali by avoiding the onslaught of the modern world with its ruinous effects. The cultural policy of Balinisation, launched in the 1930s, was the method; what it actually meant was Bali being saved for the tourists, and the Balinese getting taught how to be authentically Balinese by their Dutch colonial masters. ${ }^{26}$

Both Spies and Bonnet were exceptional among European artists in Indonesia because they ignored the colonial hierarchy and lived closely with the local Balinese at Ubud. This must have appealed to Schoon, who had his own childhood experiences of feeling most at home in the Javanese villages, free from the restrictions of Dutch colonial society. But these artists were also a product of their time, and their attitudes and beliefs aligned quite closely with colonial policy. Life in the Dutch East Indies was segregated, with relatively little formal social or cultural contact between Dutch and Indonesian communities. Dutch people were expected to embrace and admire modern Dutch culture, which was imported by the government as a prophylactic against the everpresent threat of "going native". The traditional local cultures were for the natives. ${ }^{27}$ As far as art was concerned, the colonial government divided it into two broad categories: "modern western art" for Dutch inhabitants, and "traditional oriental art" for Indonesians. The division kept the "natives" focused on timeless arts and crafts appropriate to their place in the social hierarchy, while Europeans embraced the art forms of the modern world. Art helped to maintain the gap between east and west, which was itself an artificial construction to keep the colonial social hierarchy intact. ${ }^{28}$

Bonnet, for example, believed that Balinese art should be kept free of western influences, just as colonial policy worked hard to keep Balinese people "oriental" because this is what was best for them. Bonnet believed that traditional Balinese culture was right for the Balinese because he shared colonial assumptions about their "unspoiled character" and "purity." The task that he and Spies gave themselves was to protect local artists from the damaging effects of modern life, whether it be tourism, technology, or modern art movements. ${ }^{29}$

Journal of New Zealand Studies NS27 (2018), 50-73

https://doi.org/10.26686/jnzs.v0iNS27.5176 


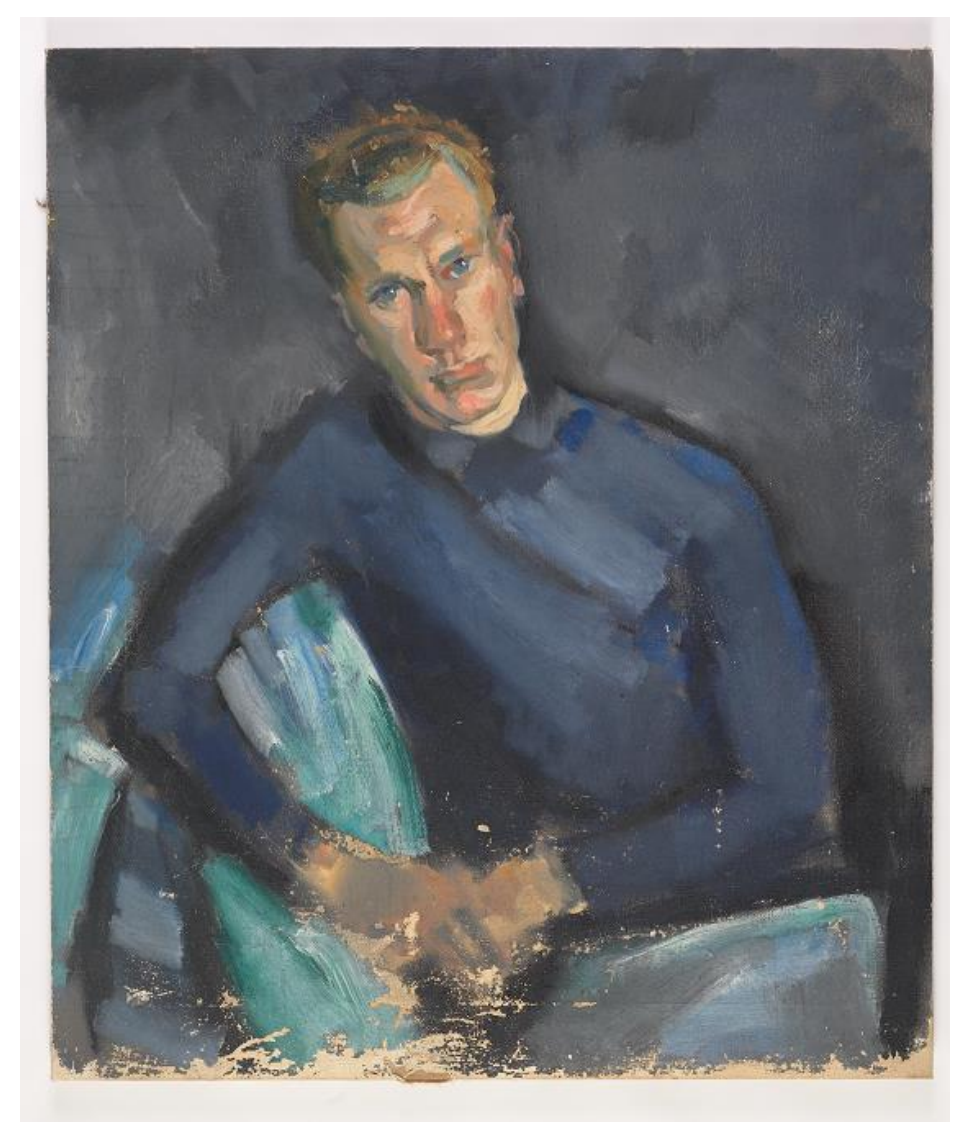

Figure 8: Gordon Walters, circa 1942.

Painting by Theo Schoon. Te Papa Tongarewa, 2006-0025-1.

\section{III}

In 1939, Schoon arrived in Aotearoa with his parents and brother. Why they came is complex. Schoon's father had retired, and he had not liked the "sound of so much goose-stepping" when he and his wife visited the Netherlands in 1937; they decided to settle in a country on the other side of the world, where the disconcerting rise of Adolph Hitler seemed, at the time, far away. ${ }^{30}$ The Dutch citizens of the Indies were also feeling threatened by Japan's growing militarism in the Pacific, making the future of the colonies uncertain. And these political pressures had upset the delicate social and moral balance of the Dutch East Indies, especially in terms of the official attitude to homosexuality. The willingness to overlook sexual activity that in Europe would be branded moral degeneracy evaporated in the growing hysteria - fed, in part, by the belief that if officials cracked down on gay activities then conservative American politicians would be more willing to support the Dutch East Indies if war broke out. Schoon was a young gay man, and Java was no longer a safe place for him and his friends. 


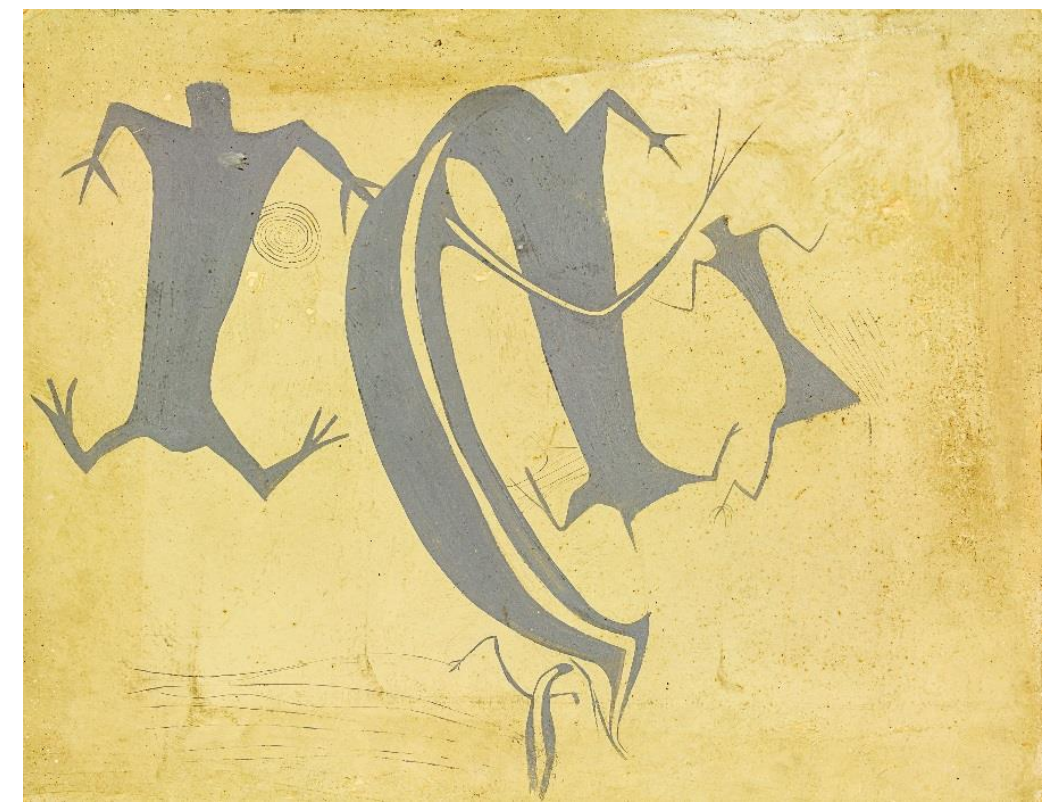

Figure 9: One of Schoon's rock drawing copies, painted at Ōpihi in 1946. In these earliest panels, Schoon made an effort to reproduce the textured effect of the limestone wall. Private Collection.

Schoon's first encounter with Māori art came at the end of the Second World War. Seeing copies of the Māori rock drawings in the Otago Museum in Dunedin, he became fascinated by these images of birds, fish, dogs, people and abstract patterns drawn onto limestone walls in South Canterbury and North Otago. They were remarkable, especially because they did not rely on any of the usual tricks of western art that Schoon had learned at the Rotterdam Academy. He still remembered the excitement of seeing African and American Indian rock drawings in the books that caused such a stir in Europe in the 1930s; here in Aotearoa, overlooked by both archaeologists and artists, was a form of art that could be the basis of something extraordinary.

In July 1946, Schoon began making painted copies and photographing the rock drawings, at first for the Canterbury Museum, and then for the Department of Internal Affairs. It was a job that continued for another two years, until August 1948. Schoon was exhilarated by what he encountered. "Finding new drawings has become a routine," he wrote, "but I am deeply moved by their purity and baffling originality." 31 The drawings of humans and animals were not naturalistic in any way, but Schoon believed there were rules and conventions that the artists were following - just not the same ones as academic European art. The results of this artistic system were baffling and marvellous, and all created with only three colours: red ochre, black charcoal, and white created by rubbing limestone against limestone. ${ }^{32}$ Schoon would first take a photograph wherever possible, and make a pencil sketch with detailed notes about the colour, materials used and location. The painted copy was last. Where the drawings were faded and unclear, Schoon would sometimes touch them up. ${ }^{33}$ He used large grease crayons, one black and one red, filling in missing sections as well as enhancing marks that were faded but still visible, so his camera would record them more easily. ${ }^{34}$ 
The artistic exhilaration came at great personal cost; sometimes the conditions in which he worked were appalling. When Schoon moved to the Ōpihi River just south of Temuka to work in the shelter with the famous taniwha frieze in September 1946, initially he did not have any accommodation. "Owing to rain and darkness, I was left at the wrong place, and was forced to sleep in the rain to keep the painting materials dry," he wrote to the local officer of the Department of Internal Affairs. ${ }^{35}$ The hut offered by the local farmer leaked constantly in the week of almost continuous rain and snow, and was threatened by rising flood waters. In his diary, Schoon wrote of the cold wind that blew while he was painting, forcing him to take constant exercise to keep warm and interrupting his progress. ${ }^{36}$ A bout of influenza left him ill for a week, and the copy of the frieze was not finished until Sunday 13 October.

These years clearly changed Schoon. "I learned a great deal, artistically and spiritually that I could not have learned in any other way or elsewhere," he wrote much later. "It has formed my character and my sense of aesthetics, living close to and in nature in years of solitude." 37 The intense and imaginative encounter with the rock drawings resulted in a huge number of interesting paintings, a large number of which can reasonably be claimed as Schoon originals rather than scientific copies. ("His weakness as a copyist is that he was satisfied as soon as he saw them that the drawings had a magical purpose, and are of extreme artistic merit," the anthropologist Roger Duff wrote to H. D. Skinner, director of Otago Museum, in June 1947, "so that in interpreting the general shadowy remains on any shelter, he is under a severe temptation to highlight those which seem to conform to the modernisms of Paul Klee, or Picasso, and neglect those which don't." ${ }^{38}$ ) For the first time, Schoon began to paint like a modern artist, triggered by this deep encounter with the artistic evidence of another culture's creativity.

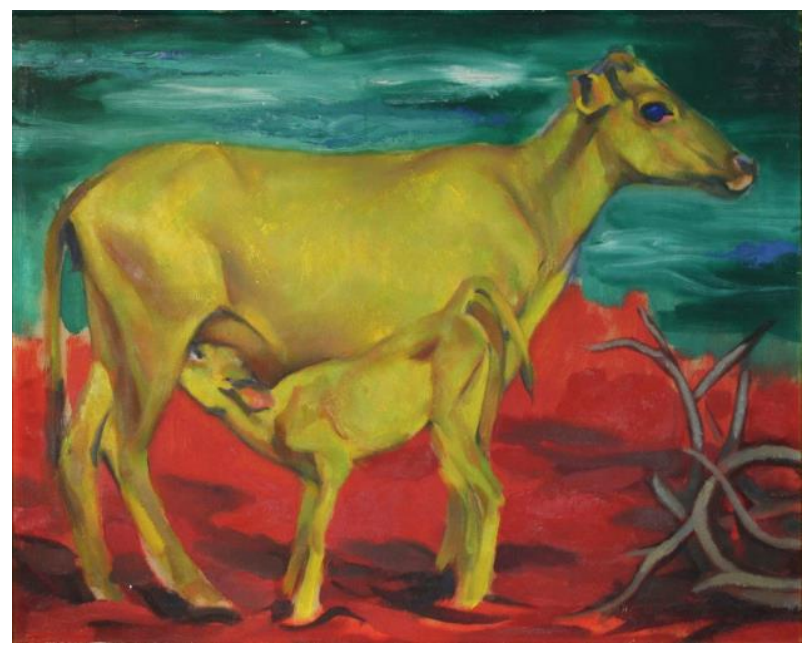

Figure 10: The Golden Cow of New Zealand, circa 1947. Painted by Theo Schoon. Eastern Southland Gallery, Gore JMC 02.230. 
But the experience changed him in another way, too. These three years brought him face to face with the coarseness and small-mindedness of many New Zealanders. The world that Schoon entered in 1946 was one of beer and Saturdays dominated by men listening to all-day race commentary, checking their "two-bob" bets with the local bookie. Anything different was, by definition, not manly. This was the world Bill Miller remembers as a 17-year-old tractor driver working on Clelland's farm, about 10 kilometres outside Pleasant Point. Schoon, he recalls, was feared by the locals because he knew about things that other people did not even know existed. When he turned up on the farm to photograph and paint the local rock drawings, he was ostracised because he was foreign. Mr Clelland sent Schoon to the married couple's cottage to organise his meals, but the woman refused to have him in her house because he spoke "funny". ${ }^{39}$ One day, while Schoon was asking the musterers about where other drawings might be, he was interrupted by shouts of laughter as a sheep dog urinated on a large painting of a golden cow and calf that he had left against the shearing shed wall; Schoon was brought to tears. As Miller wrote, "I remember Theo's great sadness - none of the Maoris he had spoken to about the drawings had shown the slightest interest in their own historical art." 40

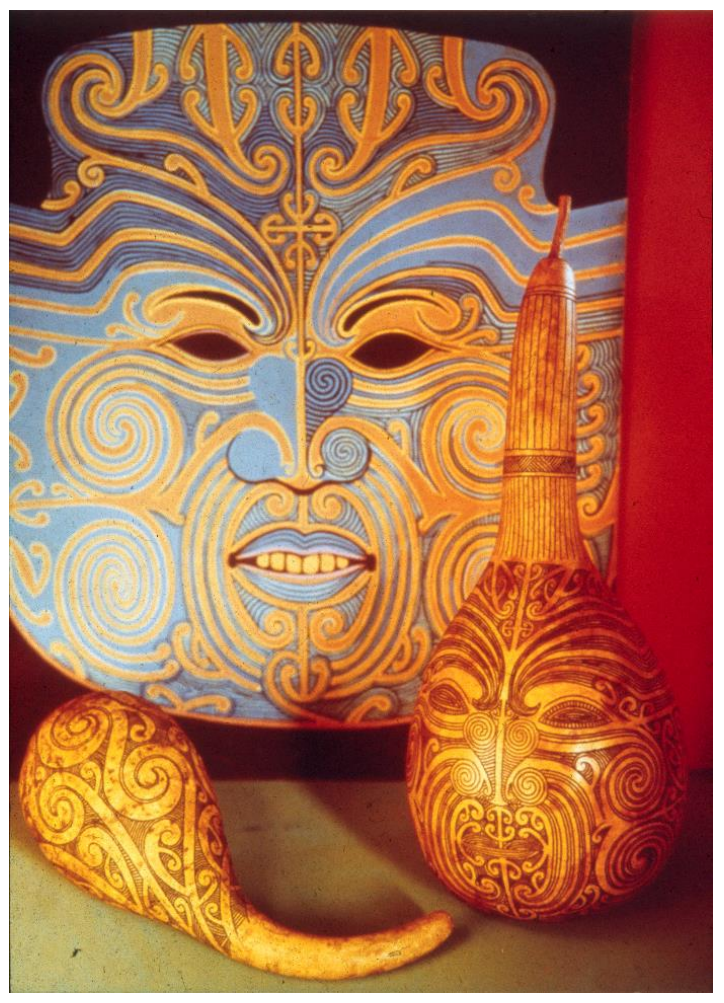

Figure 11: Gourds decorated with designs based on tā moko patterns were Schoon's first experiments in gourd carving. Quite often he would display them against backdrops painted with patterns based on tā moko or kōwhaiwhai. Photograph by Theo Schoon, circa 1960. Te Papa Tongarewa. 000840/001/0048.

Journal of New Zealand Studies NS27 (2018), 50-73

https://doi.org/10.26686/jnzs.v0iNS27.5176 


\section{IV}

In the early 1950s, looking at carved gourds in the Auckland Museum collection, Schoon realised there was a connection to Māori moko (tattoo). As he wrote in 1962, "I discovered one day that the patterns on decorated gourds were identical to many Tattoo patterns and from then on, every single gourd or even fragments of them in our Museum collections became of great importance to me." ${ }^{41}$

Copying what he saw was Schoon's first step in understanding any new art form. He began to photograph and sketch all the moko patterns he could find, including the moko mokai (preserved heads) that were, in the 1950s, on public display in New Zealand museums. He realised that he could draw and paint moko designs by flattening them out and turning them into two-dimensional silhouettes of a human face. But Schoon's desire to recreate a process in order to understand it as fully as possible could not be satisfied by paper, canvas or board when it came to the connection between moko and gourds. He believed that some gourds had been carved with parts of an individual's moko, which meant that what looked, to untrained eyes, like a decorative pattern, was actually a kind of portrait, just not a naturalistic one. ${ }^{42}$ If learning meant doing, then Schoon needed to get some gourds that he could design and carve himself. Asking around, he finally met some of the people who were still growing gourds, but none of them were as good as the old ones he had seen in museum collections. Interest grew into a full-fledged obsession, and Schoon decided to grow his own specimens. ${ }^{43}$

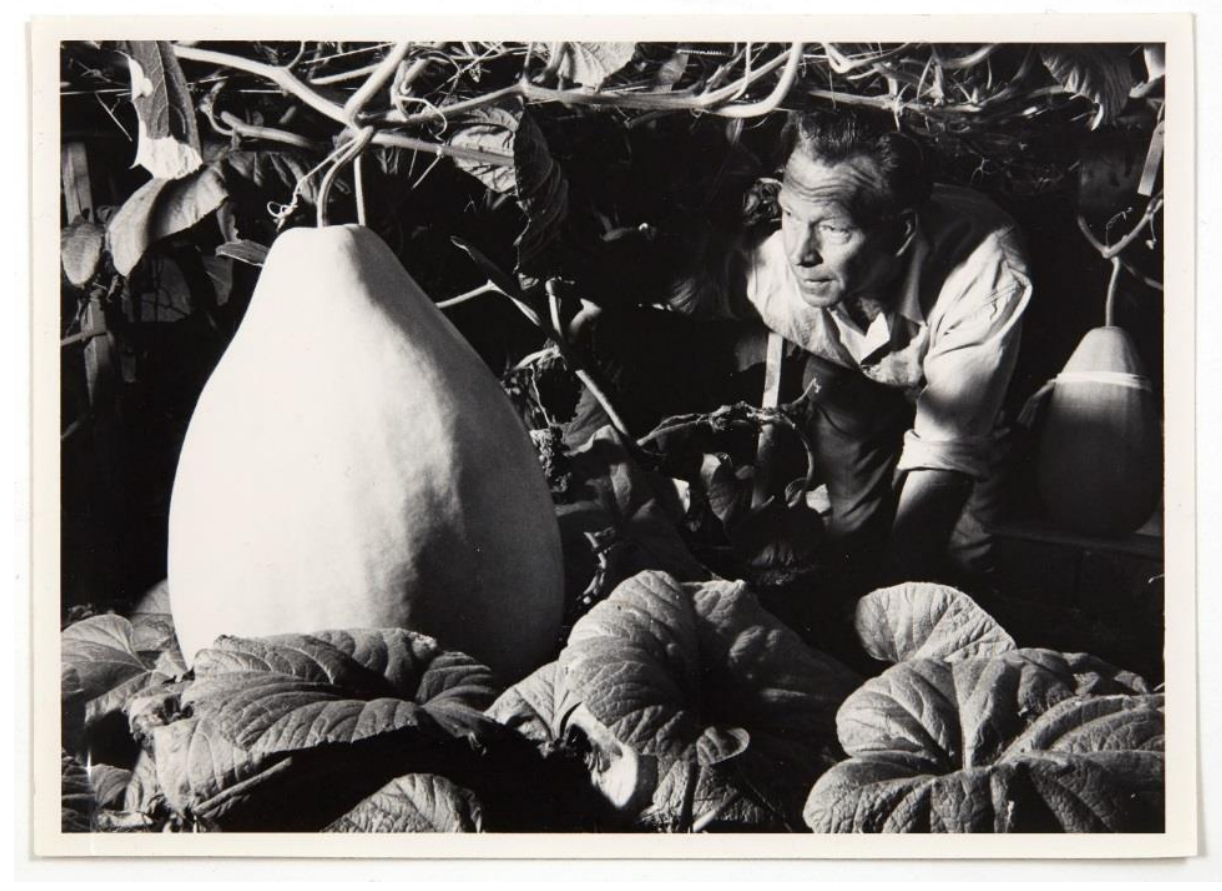

Figure 12: Theo Schoon in the garden at Home Street, 1961. Photograph by Steve Rumsey. Christine Fernyhough Collection. 
Schoon had been thinking about and documenting Māori art since the mid-1940s, when he made his first trip to the limestone caves of the South Island. But it was only when he started growing gourds in Auckland a decade later that he began to have active and purposeful contact with Māori experts, artists and communities. Schoon began to meet people who saw these art forms as central to their identity, and who were prepared to assert ownership — not just of the art forms themselves, but also of their meanings and significance.

One of Schoon's favourite identities in this period is as a kind of antipodean Johnny Appleseed, spreading gourd seeds to Māori communities throughout the land. For a trip to the East Coast of the North Island in 1961, Schoon loaded his car up with a dozen carved gourds and plenty of seeds. "Wherever I stopped near or in a Maori settlement to make a cup of tea or some lunch," wrote Schoon, "I surrounded myself with gourds. Within ten minutes a crowd of Maori children would have gathered around me, asking lots of questions. Then they would run off home, and soon parents would come to have a look. I have distributed seeds in more than 30 Maori villages in this way, and it will be interesting to watch the developments. As a rule, it is the elderly people who recognise the gourds at first glance, and who are overjoyed at the prospect of growing them once more." $" 44$

The reason Schoon was visiting this part of the country in 1961 was to visit the famous Ngāti Porou carver and cultural expert Pine Taiapa. Taiapa had a storied career. He was one of the first intake of students to the Rotorua School of Māori Arts and Crafts, an initiative established by Sir Āpirana Ngata through an Act of Parliament in 1926 to foster the arts of the Māori meeting house that were in serious decline. Taiapa worked as Ngata's right-hand man, taking the lead on the series of meeting house projects that the School completed in the 1930s and 1940s. After Ngata died in 1950, Taiapa gave up full-time carving and returned to farm sheep on family land in Tikitiki on the East Coast. But he remained extraordinarily active in the 1950s and 1960s, becoming involved in adult education around the East Coast and as far away as Wellington, writing articles for magazines like Te Ao Hou, and publishing booklets about the various meeting houses he had been associated with. He was a brilliant orator, fluently switching from Māori to English, and a kind, charming and patient teacher who left a huge impact on both Māori and Pākehā students.

By early 1961, Schoon had begun corresponding with Taiapa. "He did not answer my first 2 letters, but when I sent him photos of my gourds, letters poured into my mailbox," Schoon wrote to his old friend and fellow gardener Graham Miller. "Showing him my photos and drawings made his eyes pop." 45 In May, Schoon packed up a borrowed Volkswagen with carved gourds and gourd seeds, and set off on a road trip that would eventually take him to Taiapa's house in Tikitiki. He was joined by Margaret Orbell, a young Pākehā scholar who was planning to write a book about Māori art. While Schoon did not often get on very well with women, he liked Orbell, and when she told him about her planned book, he helped her master the rudiments of photography. And when she decided that a trip to the East Coast to photograph meeting houses was required, Schoon jumped at the chance to come along and meet the man he had been corresponding with.

Journal of New Zealand Studies NS27 (2018), 50-73

https://doi.org/10.26686/jnzs.v0iNS27.5176 


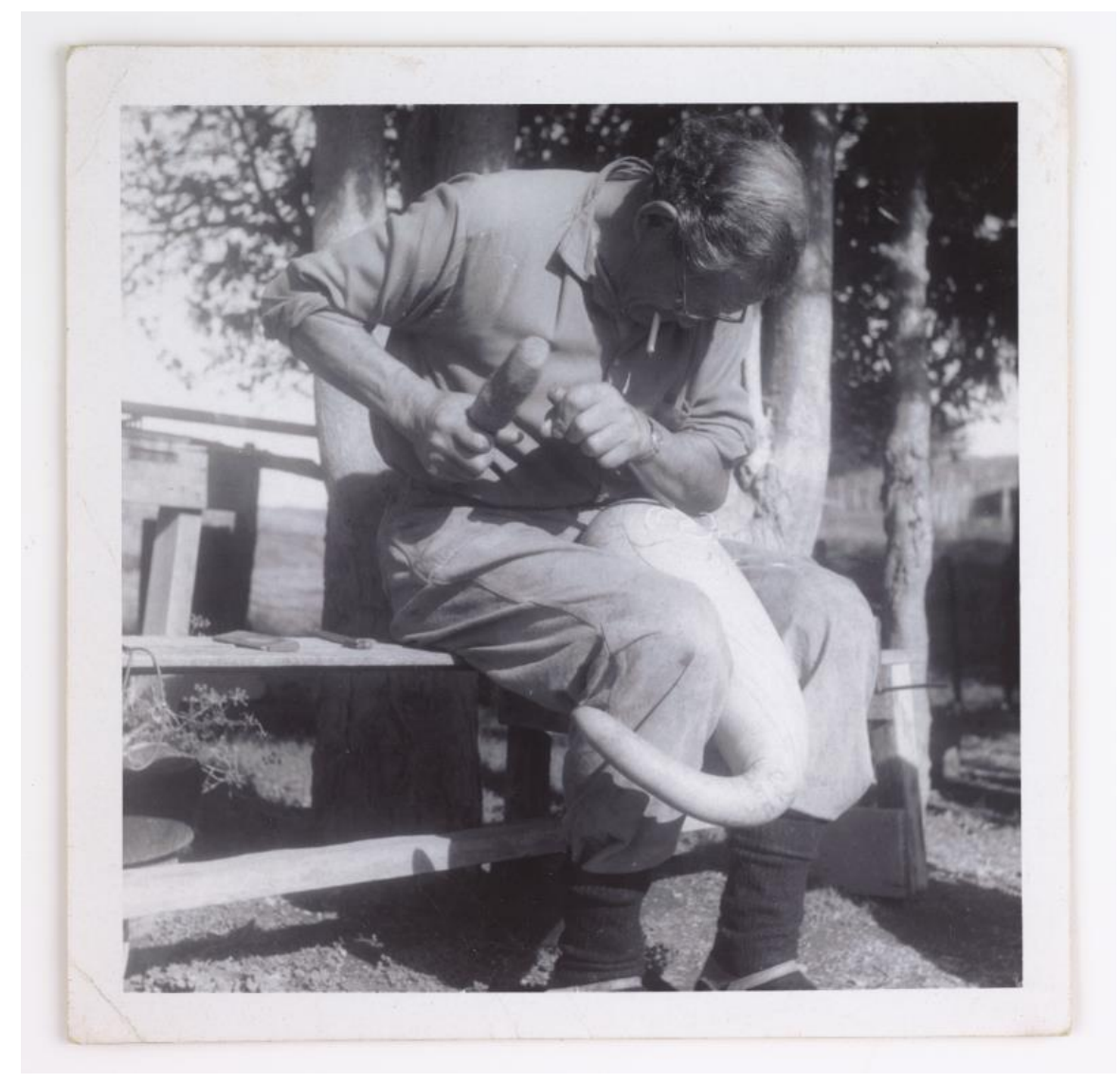

Fig.13 Pine Taiapa carving a gourd, Tikitiki, 1961. Photograph by Theo Schoon. Te Papa Tongarewa, CA000221/001/0001/0003

Schoon and Orbell stayed with Pine Taiapa and his wife at Tikitiki for about a week. There were plenty of drives around the countryside, which became opportunities for some intense discussions about what Schoon was experiencing. According to Orbell, "Theo tended to swing violently in his approval or disapproval of individuals, and his expectations had been high where Pine was concerned - I think this was the first time he'd met him — and then he found that the reality was more complex than that and, temporarily at least, swung away." As they drove along the unsealed country roads, the two argued vigorously about Taiapa. "I simply said, "Look, he's doing his own thing and his own thing is not perhaps what you might have envisaged." He'd identified Pine with a revival of Māori art that would take it in new directions, and he considered what he saw to be too narrowly traditional." But there was also another problem: "I think one thing was that Pine wasn't really paying a lot of attention to Theo's ideas. This is a fairly general fact about Theo that he wanted to talk to people and to indeed instruct them." 


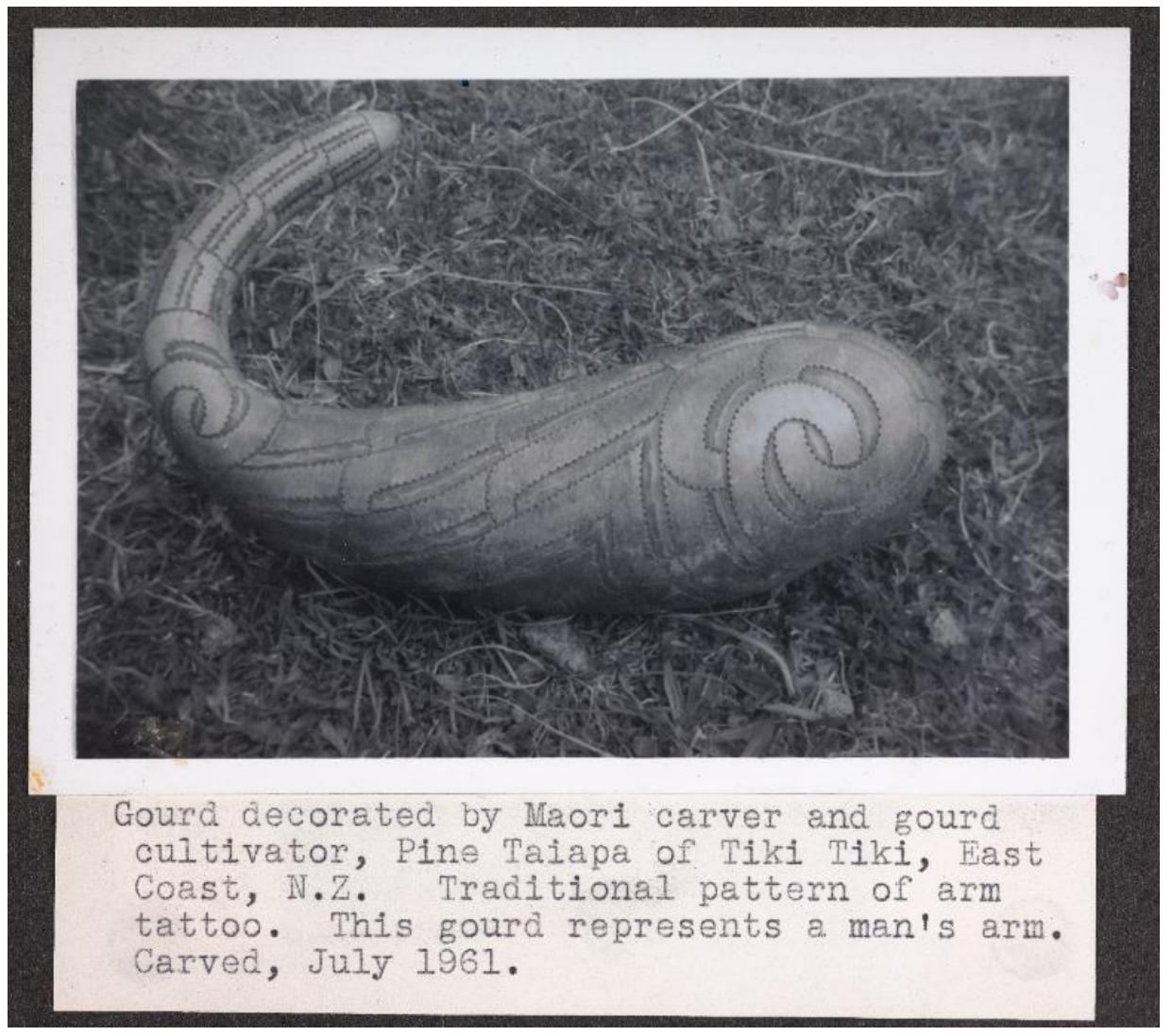

Fig. 14. One of Pine Taiapa's carved gourds, 1961. Photograph by Theo School. Te Papa Tongarewa, CA000219/001/0001/13.

Writing to Graham Miller a few days after he returned to Auckland, Schoon told him "This trip has been a surprise beyond anything I could have dreamed of. Apart from the many unsuspected old carvings still to be found in out of the way places, I stayed with Pine Taiapa, the Maori carver. He is a very colourful character, and a spell binding story teller." The main revelation was seeing how Taiapa carved his gourds. "Using only two chisels and a small manuka mallet, he cut his patterns with a swiftness sureness and ease, as if he was carving into soap or cheese," wrote Schoon. "He does only some rough sketching on his gourd, to guide him. The precision and perfection of his curved cuts is amazing. Holding the gourd between his knees, he finishes his large and small spirals with a minimum of interruptions, guiding his chisel by turning the upper part of his body and the position of his arms. The ease of his carving is very deceptive, as no doubt this can only be the result of great skill, knowledge and experience. The chisel moves along swiftly with a gentle rapid tapping of his mallet."46

It was not just technique that impressed Schoon. Taiapa was, in Schoon's words, as fussy as an old maid when it came to talking about the principles of design, and this was something that Schoon admired, writing later that "I should think that many superficial and impatient students rejected him out of hand and in anger." 47 So they talked more widely about Māori art, with Schoon grateful that his own studies in the 1950s had equipped him with enough knowledge to 
keep up. Despite the reservations that Schoon had expressed to Orbell on their road trip, Taiapa was thoroughly impressive. As Schoon wrote, "Pine came to his teachers with respect and reverence but it did not take him very long, to rediscover the craft for himself and know more than his teachers in a short time. One of the few Maoris with an alert analytical gift." 48

Yet Schoon had doubts about Māori artists, including Taiapa. They suffered from what Schoon believed to be a generally impoverished artistic culture. Over time, he argued, Māori had taken on the "rather dismal Pakeha artistic and cultural outlook," and added to this, the best local examples of Māori art were carried off to museums in the main centres, leaving young talents with nothing to feed them, and the tohunga with the knowledge were secretive and unwilling to divulge what they knew. In a letter to Charles Devonshire, director of the Whangarei Museum, written just after his visit to the East Coast, Schoon wrote: "Pine Taiapa told me that he was virtually enslaved, and taught little by little over many years, but never received a really intensive training from what he considers one of the finest old carvers in his district. He was also trained at the Rotorua carving school where he was considered an 'Outsider' and told that he would never be taught their local 'secrets.' Pine rightly and contemptuously said, 'They didn't have any.",49 Taiapa, said Schoon, really learned from studying and copying old taonga, on marae and in museums, which was the same way Schoon himself had learned about Māori art.

Schoon saw in Taiapa a talented artist who had been brutalised by the culture in which he worked. He saw, in other words, someone exactly like himself. "I have never had a decent or adequate commission in the 20 years I have been here, and I can understand that Pine must have lost all appetite for this kind of blessing in his own world," he told Devonshire. "Pine never harvested recognition or reward for his exceptional skill, and all that we have left of him is a very bitter, weary and intractable man - is it any wonder?" ${ }^{50}$ Encouraging keen young artists to make their work without a community which would support them or take pride in the possession of their art, could only result in misfits and unhappy individuals. At this point, Schoon is not so much talking about Taiapa as he is talking about himself, a misfit grown very bitter, weary and intractable by what he saw as the ignorance and cruelty of New Zealanders. "Pine is a very difficult fellow, a neurotic as the result of our wonderfully barbaric attitude to art and artists here!" Schoon wrote in another letter. "He is an odd mixture of kindliness and megalomania, brilliance and stupidity, sincerity and downright crookedness." 51 Schoon might as well have been - in fact really wasdescribing himself.

Yet Schoon's insights were blinded by his own sense of superiority. The key to understanding Taiapa, he told Devonshire in yet another letter, was that he was a neglected genius, a great man affected by the misfortunes of a poor education, a disintegrating Māori social and cultural system, and the philistine attitudes of all New Zealanders towards the arts. "It has been bad enough to drive me nearly crazy and sick with hatred, let alone a talented Maori without defences of any kind, or even an insight in his own and his people's problems." ${ }^{2}$ While they faced the same problems, Schoon obviously believed he had been able to overcome them, or to make sense of them, unlike Taiapa, who remained a victim. The result was irreconcilable opposites: staggering craftsmanship, a spellbinding storyteller, a self-educated man with blind prejudices and gaps in his knowledge, a sheep thief, a generous artist who funded a meeting house from his own pocket, 
a haphazard gourd cultivator who swore by the Māori calendar for planting seeds. "He is a mixture of very very good and very very bad," Schoon concluded. ${ }^{53}$ Unlike Schoon himself, who presumably was just mostly very good.

Fundamentally, Schoon believed that modern civilisation had corrupted Māori values. "You can see it here in New Zealand," Schoon wrote in February 1962, "where leading Maoris, Europeaneducated, take pleasure and pride in owning the plaster of paris doggie, bunny, pixie, and even the Venus de Milo sprayed with a ghastly pink, on a chrome pedestal. Not one of them owns a fine carving. $"{ }^{\circ 4}$ Here he repeats a version of the ideas he first absorbed in Java and Bali in the 1930s: indigenous peoples should stick to indigenous culture, because the modern world could only be a path to cultural degeneracy and artistic ruin.

Schoon had a complicated relationship to Māori art. He professed his love for it, writing in the early 1960s that "I was not born to it by birth, race, or inheritance, but I love it as if it was my own." And he professed his dismay at the general attitude in New Zealand towards Māori art. "That New Zealanders, Pakeha or Maori could have failed in such a response and recognition is beyond my understanding," he said, "unless I can accept that you are a people with hearts and minds of stone." Since he did not think that was true, there was only one other conclusion: New Zealanders were artistic snobs, who could not see the value and richness of Māori art. Having decided it was "primitive," it was dismissed as only good for children, and never taken seriously or properly studied and examined. The only name for that, in Schoon's opinion, was snobbery. He fought against this attitude in his art, and in his life, by taking Māori art extremely seriously.

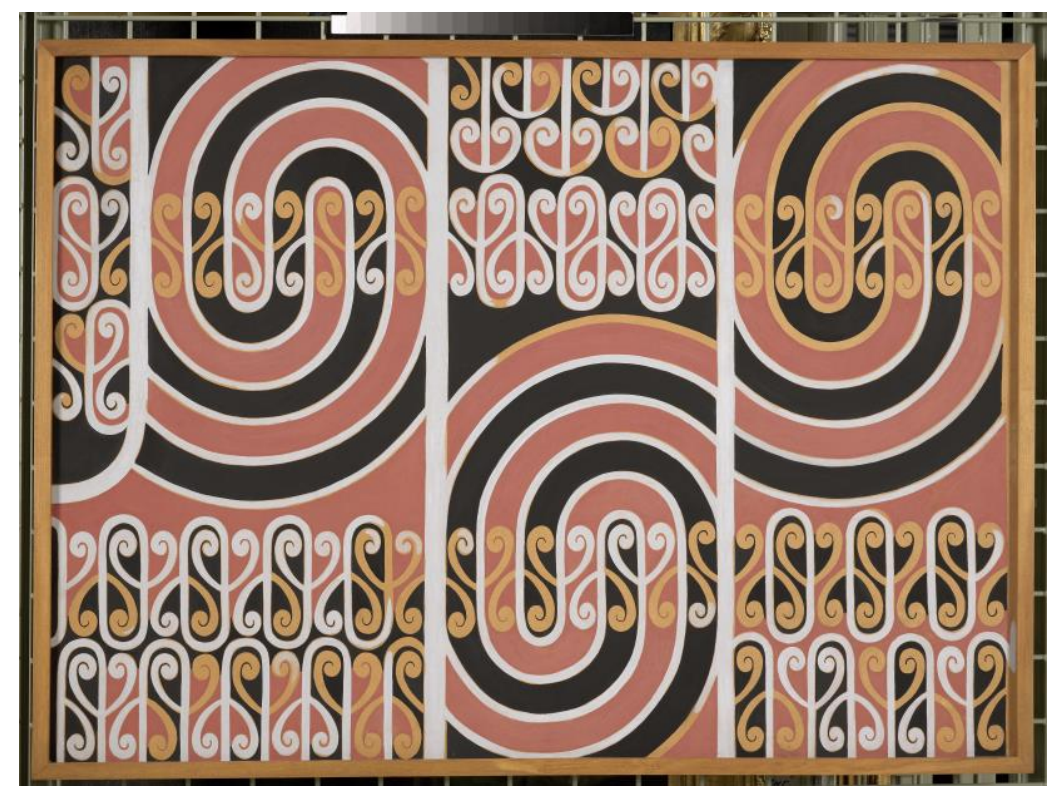

Figure 15: Untitled Painted Panel, circa 1959.

Painting by Theo Schoon. Te Papa Tongarewa 1993-0008-1. 
But while Schoon was scornful about the ignorance of New Zealanders, when it came to Māori art he was also scornful of Māori artists and the communities that sustained them. (Those modern houses owned by European-educated Māori, filled with pink Venus de milos and not a single fine carving.) At the heart of his attitude was the problem of authenticity. By the early 1960s, Schoon was comfortable suggesting that he had been initiated into the secrets of Māori art in a way that gave him a privileged status; as he put it, "Once you know how the old patterns were made, you can make new ones which remain perfectly true to tradition, and are quite authentic." 55 It was a bold claim. Growing and carving gourds in inner city Auckland in the late 1950s and early 1960s, and studying Māori art in books and museums, like Schoon did, had nothing in common with the experiences of the Māori artists who produced moko and carved gourds in the nineteenth century - or those Māori artists who were continuing to make customary or traditional Māori art in the mid-twentieth century.

The problem of authenticity conspired with the colonial values that Schoon absorbed from his time in the Dutch East Indies; the result was a set of contradictions as impossible to solve as the ones Schoon thought he saw in Pine Taiapa. Schoon loved Māori art, but he also could not see it clearly, and his love involved diminishing that which he professed to cherish. Increasingly, he had to rewrite his encounter with Māori art and artists to fit his own sense that his work - and his attitudes - offered a solution to his diagnosis of degeneracy. Unfortunately, Schoon decided that establishing his own expertise in these matters required devaluing anyone else's contribution, especially the Māori artists who could also make a claim to carrying customary Māori art into the future. Only a few years after proclaiming his visit to Taiapa an impressive experience, Schoon was narrating his trip as a story about cultural degeneration. "I know exactly how it happens too, I saw it at Pine Taiapa's hovel, when I stayed with him for over a year to take lessons in carving," wrote Schoon in 1967. "His hovel was infested with rats, who were so aggressive that they chewed at me during the night. Pine Taiapa remained quite undisturbed about this fact, or that they were spoiling food and dozens of his gourds. I bought 6 rat traps, but Pine could not be bothered to empty them and reset them during the night, as I did." This was not poverty, Schoon continued, given that Māori earned the same wages as Pākehā. Rather, it was evidence of the collapse of Māori cultural laws, and the refusal to accept the discipline of European culture in its place. "The Welfare State, believes that all human problems are economic. But man lives by the nourishment and sustenance of a cultural heritage even more, than by his belly."56

Of course, Taiapa did not live in a hovel, and Schoon did not stay with him for a year to take carving lessons. If there were any rats, it was not something that Schoon-a terrible housekeeper himself - thought worth mentioning in any of his letters to friends at the time. Most likely, because any literary hovel worthy of the name has rats, it became necessary to invent some. In Schoon's letter to Francesca Mayer, Taiapa was no longer an actual Māori artist whom Schoon visited in May 1961, but a cultural trope - the demoralised native craftsman, so far gone that he could not even accept help when it came in the form of an enlightened Dutchman who happened to have all the artistic answers. Given that there was no hope for Taiapa and the other Māori artists devastated by colonialism, it was necessary to look elsewhere for a future. Enter Schoon. "I am glad," he concluded, "that as a Dutchman and stranger, I have been able to salvage some

Journal of New Zealand Studies NS27 (2018), 50-73

https://doi.org/10.26686/jnzs.v0iNS27.5176 
of this know how." ${ }^{57}$ At the very moment Schoon extolled his outsider status and his difference to the average insensitive New Zealander, he had never sounded more like a Pākehā.

\footnotetext{
${ }^{1}$ This article was first presented as the J.D. Stout Annual Lecture on Wednesday 4 October 2017.

${ }^{2}$ Theo Schoon, letter to Virginia Umberger, 25 September 1961, p. 1, CA000216, Te Papa Tongarewa, Wellington.

${ }^{3}$ Theo Schoon, letter to Francesca Mayer, no.16, p. 1, CA000505, Te Papa Tongarewa, Wellington.

${ }^{4}$ Ibid.

${ }^{5}$ Theo Schoon, letter to Michael King, ps304, pp. 3-4, 85-080-01/13, National Library, Wellington.

${ }^{6}$ Nancy Pell translation of information from the Centraal Bureau voor Genealogie, received February 1997. Damian Skinner Archives.

${ }^{7}$ Theo Schoon, letter to Francesca Mayer, no.15, p. 2, CA000505, Te Papa Tongarewa, Wellington.

${ }^{8}$ Theo Schoon, "The Art of Njoman Suara," New Zealand Potter 25, no.1 (Autumn 1983): 21.

${ }^{9}$ Theo Schoon, letter to Virginia Umberger, 10 November 1961, p. 1 CA000216, Te Papa Tongarewa, Wellington.

${ }^{10}$ Theo Schoon, letter to Gordon Walters, AA, c.1981, pp. 2-3, CA000044/001/0001, Te Papa Tongarewa, Wellington.

${ }^{11}$ Theo Schoon, letter to Virginia Umberger, 25 September 1961, p. 1, CA000216, Te Papa Tongarewa, Wellington.

${ }^{12}$ Gerald Moonen, interview with Damian Skinner, 12 December 1998, OHInt-0792-11, National Library, Wellington.

${ }^{13}$ The Rotterdam state archives record that Pieter Schoon arrived in the city from Kebumen on 27 June 1927, and since all accounts have the two brothers being sent to the Netherlands together, Theo Schoon must have travelled with him. Wilma van Giersbergen, email to Damian Skinner, 16 August 2017, 494-03 Archief van de Gemeentesecretarie Rotterdam, afdeling Bevolking bevolkingsboekhouding van Rotterdam en geannexeerde gemeenten, inv. nr. 851-425, pag. 455506.

${ }^{14}$ Wilma van Giersbergen, email to Damian Skinner, 19 May 2017.

${ }^{15}$ In an interview with Ron Brownson, Schoon says that he read about the Bauhaus and other modern art movements in German-language texts, and that this was one of the three languages he studied (Theo Schoon, interview with Ron Brownson, 14 April 1982, Ron Brownson Archives). Another must have been English because he was clearly able to speak the language before he arrived in Aotearoa in 1939, based on his career as a lecturer soon after he and his family settled in Christchurch.

${ }^{16}$ Theo Schoon to Neil Roberts, 26 March 1985, p. 1, Archive 53, Robert and Barbara Stewart Library and Archive, Christchurch Art Gallery Te Puna o Waiwhetū.

${ }^{17}$ Theo Schoon, letter to Francesca Mayer, no.12, 1960s, p. 3, CA000505, Te Papa Tongarewa, Wellington.

${ }^{18}$ Theo Schoon, letter to Francesca Mayer, no.16, p. 1, CA000505, Te Papa Tongarewa, Wellington.

${ }^{19}$ This description is based on a letter written by the artist Walter Spies, who made the same train journey as Schoon in 1923, thirteen years earlier (John Stowell, Walter Spies: A Life in Art [Jakarta: Afterhours Books, 2011], 75).
}

Journal of New Zealand Studies NS27 (2018), 50-73

https://doi.org/10.26686/inzs.v0iNS27.5176 
${ }^{20}$ Helena Spanjaard, Modern Indonesian Painting (The Netherlands: Sotheby's, 2003), 23.

${ }^{21}$ Leo Haks and Guus Maris, Lexicon of Foreign Artists Who Visualised Indonesia (1600-1950) (Utrecht: Gert Jan Bestebreurtje, 1995), 239.

${ }^{22}$ Michael Hitchcock and Lucy Norris, Bali: The Imaginary Museum-The Photographs of Walter Spies and Beryl de Zoete (New York: Oxford University Press, 1995), 28-29.

${ }^{23}$ Quoted in Stowell, 191.

${ }^{24}$ Ibid.

${ }^{25}$ Helena Spanjaard, Pioneers of Balinese Painting: The Rudolf Bonnet Collection (Amsterdam: KIT Publishers, 2007), 112.

${ }^{26}$ Hitchcock and Norris, 3, 24.

${ }^{27}$ Helena Spanjaard, Artists and Their Inspiration: A Guide Through Indonesian Art History (The Netherlands: LM Publishers, 2016), 21.

${ }^{28}$ Spanjaard, Artists and Their Inspiration, 23.

${ }^{29}$ Spanjaard, Pioneers of Balinese Painting, 115.

30 "Dogs and rats," Evening Post, 1 December 1945, 9.

${ }^{31}$ Theo Schoon, letter to A. R. D. Fairburn, 1947 [D], p. 1, A 125.17, University of Auckland Library.

${ }^{32}$ Theo Schoon, letter to A. R. D. Fairburn, 2 June 1947, pp. 7-8, A 125.17, University of Auckland Library.

${ }^{33}$ John Money, quoted in Michael King, "John Money: Scientist, Eccentric, Patron of the Arts," in Splendours of Civilisation: The John Money Collection at the Eastern Southland Gallery, ed. Jim Geddes (Gore: Eastern Southland Gallery and Longacre Press, 2006), 33.

${ }^{34}$ As Tony Fomison wrote in 1987, there were a number of problems with Schoon's decision to retouch the drawings: his red was a single colour, even though the red used by the original artists varied from near-purple to yellow-orange; he didn't attempt to cover mark for mark; he sometimes amalgamated a later drawing superimposed over an earlier one into a single image; and he often retouched the drawings before they had been photographed (Tony Fomison, "Rock Art Retouching: Theo Schoon" [unpublished manuscript, 1987], 1-5. Theo Schoon Artist Files, E. H. McCormick Research Library, Auckland Art Gallery).

${ }^{35}$ Quoted in Neil Roberts, "Maori Rock Drawing and Theo Schoon," in Maori Rock Drawings: The Theo Schoon Interpretations, ed. Neil Roberts (Christchurch: Robert McDougall Art Gallery, 1985), unpaginated.

${ }^{36}$ Theo Schoon, Diary Notes, Microfilm 3564, National Archives, Wellington.

${ }^{37}$ Theo Schoon, letter to Neil Robert, 26 March 1985, p. 3.

${ }^{38}$ Roger Duff, letter to H. D. Skinner, 20 June 1947, p. 1, CMR 6/10 Folder 25A, Canterbury Museum, Christchurch.

${ }^{39}$ Bill Miller, interview with Damian Skinner, 17 December 1998, OHInt-0792-10, National Library, Wellington.

${ }^{40}$ Bill Miller, "Cave In: Some of my Dealings with Theo Schoon," September 1995, p. 1, Damian Skinner Archives.

${ }^{41}$ Theo Schoon, "Cultivating the Polynesian Gourd in New Zealand," Gourd Seed (February 1962): 4.

${ }^{42}$ Theo Schoon, letter to Michael King, undated (4 pages), p. 1, 85-080-01/13, National Library, Wellington.

${ }^{43}$ Schoon, "Cultivating the Polynesian Gourd," 4.

${ }^{44}$ Theo Schoon, letter to Virginia Umberger, 20 November 1961, p. 3, CA000216, Te Papa Tongarewa, Wellington. 
${ }^{45}$ Theo Schoon, letter to Graham Miller, undated, p. 2, CA000222, Te Papa Tongarewa, Wellington.

${ }^{46}$ Theo Schoon, letter to Graham Miller, 27 May 1961, p. 1, CA000222, Te Papa Tongarewa, Wellington.

${ }^{47}$ Theo Schoon, letter to Michael King, own drawings, p. 2, 85-080-01/13, National Library, Wellington.

${ }^{48}$ Theo Schoon, letter to Michael King, 25 March, p. 10, 85-080-01/13, National Library, Wellington.

${ }^{49}$ Theo Schoon, Letter to Charles Devonshire, n.d., c.1962, p. 1, T571.1, Kiwi North, Whangarei.

${ }^{50}$ Theo Schoon, Letter to Charles Devonshire, n.d., c.1962, p. 2, T571.2, Kiwi North, Whangarei.

${ }^{51}$ Theo Schoon, Letter to Charles Devonshire, n.d., c.1962, p. 1, T571.4, Kiwi North, Whangarei.

${ }^{52}$ Theo Schoon, Letter to Charles Devonshire, n.d., c.1962, p. 1, T571.5, Kiwi North, Whangarei.

${ }^{53}$ Theo Schoon, Letter to Charles Devonshire, n.d., c.1962, p. 1, T571.5, Kiwi North, Whangarei.

${ }^{54}$ Theo Schoon, letter to Virginia Umberger, February 1962, p. 1, CA000216, Te Papa

Tongarewa, Wellington.

${ }^{55}$ Theo Schoon, letter to Virginia Umberger, 30 October, p. 1, CA000216, Te Papa Tongarewa, Wellington.

${ }^{56}$ Theo Schoon, letter to Francesca Mayer, 20 September 1967, p. 2, CA000505, Te Papa Tongarewa, Wellington.

${ }^{57}$ Theo Schoon, letter to Francesca Mayer, 20 September 1967, p. 2, CA000505, Te Papa

Tongarewa, Wellington.

Journal of New Zealand Studies NS27 (2018), 50-73

https://doi.org/10.26686/jnzs.v0iNS27.5176 